DOI: https://doi.org/10.32839/2304-5809/2021-9-97-32

УДК 338.24

Пугачевська К.Й., Лисенко Е.P. Мукачівський державний університет

\title{
АДАПТИВНЕ УПРАВЛІННЯ ПІДПРИЕМСТВОМ В УМОВАХ НЕВИЗНАЧЕНОСТІ
}

\begin{abstract}
Анотація. У статті досліджено сутність понять «адаптивне управління» та «адаптивна система». Охарактеризовано генезис сучасних підходів до управління в контексті способів адаптації до зовнішніх умов. Ідентифіковано умови, за яких зростае значимість адаптивного менеджменту. Розглянуто адаптивний менеджмент з позицій управлінської концепції забезпечення конкурентоспроможності. Визначено основні засади концепції динамічного управління бізнес-процесами підприемства. Обтрунтовано, що управління змінами на вітчизняних підприемствах повинно бути оріентоване переважно не на вирішення існуючих проблем, а на використання наявних можливостей і сильних сторін підприемства. Проаналізовано вплив пандемії COVID-19 на бізнес та ідентифіковано виклики, які постають перед менеджментом підприемств в умовах коронакризи.
\end{abstract}

Ключові слова: адаптивне управління, конкурентоспроможність, зовнішне середовище, ситуаційний підхід, теорія управління.

Pugachevska Kateryna, Lysenko Erika

Mukachevo State University

\section{ADAPTIVE MANAGEMENT OF THE ENTERPRISE IN THE CONDITIONS OF UNCERTAINTY}

Summary. The spread of adaptive management was the result of the development of management theory in conditions of increasing uncertainty of the enterprise external environment. Currently, it is considered as an independent concept of management, implemented in terms of innovation, strategic management and risk management. In order to survive and maintain the enterprises competitiveness in the current conditions, systematic adjustments of their economic activity are required, taking into account changes in external environment. Despite the significant amount of work in which various aspects of management are presented, the issues of ensuring the competitiveness and economic stability of enterprises in a volatile environment remain controversial and require further study. The essence of the concepts "adaptive control" and "adaptive system" is investigated in the article. The genesis of modern approaches to management in the context of ways of adaptation to external conditions is characterized. Features of process, system, situational, reengineering, network approaches to management and the approach on the basis of knowledge management are analyzed. The importance of adaptive management increases in the period of the organization's exit from the crisis (anti-crisis management), with the introduction of innovations (innovation management), in the case of organizational change. Adaptive management from the standpoint of the management concept of competitiveness is considered. The basic principles of the concept of dynamic management of business processes of the enterprise are defined. It is substantiated, that management at domestic enterprises should be focused mainly not on solving existing problems, but on using the existing opportunities and strengths of the enterprise. The impact of the COVID-19 pandemic on business is analyzed and the challenges facing the enterprises management in the conditions of coronary crisis are identified. Simultaneously with the coronary crisis, the business is experiencing a "crisis of adaptation", learning how to work and make a profit in the new environment.

Keywords: adaptive management, competitiveness, external environment, situational approach, management theory.

Постановка проблеми. Теорії менедж1 менту першої половини ХХ ст. розвивались в умовах відносно стабільного зовнішнього середовища і орієнтувались в основному на пошук шляхів підвищення ефективності діяльності підприемства за рахунок удосконалення його управління. Поширення адаптивного менеджменту стало результатом розвитку теоріі управління в умовах підвищення невизначеності зовнішнього середовища підприемства. Нині його розглядають як самостійну концепцію менеджменту, що реалізовуеться в умовах інноваційного, стратегічного управління та ризик-менеджменту. Натомість з другої половини XX ст. підходи до управління відповідали викликам, актуальних у відповідний часовий період та зосереджували увагу на способах адаптащії до зовнішнього середовища. 3 позицій теорії систем будь-яке підприемство розглядається як систе- ма, натомість адаптивною е система, яка може змінюватись у відповідь на зміни внутрішніх і зовнішніх параметрів функціонування. Дана проблематика набуває особливої актуальності в умовах коронакризи за якої підприемства були змушені розробити нові підходи до ведення бізнесу з метою уникнення негативних наслідків пандемії, а відтак утримання власних позицій на ринку.

Аналіз останніх досліджень і публікацій. Проблематика формування адаптивного менеджменту детально представлена у працях таких зарубіжних і вітчизняних науковців, як П. Друкер, М. Мак-Дональд, Т. Мот, Д. Норт, М. Олсон, М. Портер, Дж. Еванс, 3. Калініченко, О. Тімінський, Л. Кожуріна та ін. Незважаючи на значний обсяг робіт, в яких представлено різні аспекти управління, питання забезпечення конкурентоспроможності та економічної стійкос- 
ті підприемств в умовах волатильності зовнішнього середовища залишаються дискусійними і потребують додаткового вивчення.

Відтак, метою статті є дослідження адаптивного управління в умовах невизначеності з позицій управлінської концепції забезпечення конкурентоспроможності.

Виклад основного матеріалу. Підвищення ефрективності та конкурентоспроможності підприемства в сучасних умовах господарювання пов'язане зі здатністю пристосовуватись до мінливого зовнішнього середовища. Якщо розглядати підприемство як систему, то особливістю адаптивної системи виступає можливість змінюватися у відповідь на трансформації внутрішніх і зовнішніх параметрів фрункціонування. Поряд 3 поняттям адаптивної системи виокремлюють також поняття «адаптивне управління», тобто управління в системі з неповною інформацією про керований процес, що змінюеться в міру накопичення і обробки додаткових параметрів, що необхідні для підвищення якості управління. Адаптивне управління можна розглядати як процес прийняття та імплементації управлінських рішень, що забезпечують своєчасну відповідь підприемства і всіх їі структурних підрозділів на зміну параметрів 3овнішнього і внутрішнього середовища.

Різноманітні підходи до управління другої половини XX ст. зосереджували свою увагу на різних аспектах менеджменту підприємства та способах його пристосування до зовнішнього середовища. Як наслідок, сформувались різні підходи до управління, які відповідаючи на реалії свого часу, диференціюються за суттю, принципами, особливостями, але спрямовані на ефрективну роботу в умовах змін зовнішнього середовища. Як видно 3 табл. 1, розвиток адаптивного менеджменту відбувається в рамках ситуа- ційного підходу, оскільки він передбачає оцінку конкретних змінних у відповідний момент часу, а потім - адекватну реакцію на неї.

Розвиток підприємства, що реалізуе адаптивну систему управління, матиме еволюційний характер. Але при цьому необхідно врахувати, що орієнтиром такого розвитку буде слугувати стратегічна мета, зокрема виживання в умовах несприятливого i невизначеного середовища, що в цілому можна вважати актуальним для більшості вітчизняних підприемств [8], особливо в кризових економічних умовах та в умовах коронакризи.

Значимість адаптивного управління зростає в наступних ситуаціях:

- в період виходу організації 3 кризи (антикризове управління);

- при впровадженні інновацій (інноваційне управління);

- у випадку проведення організаційних змін.

Мета адаптивного управління полягає в пошуку найбільш ефективних варіантів прийняття і виконання рішення, спрямованих на функціонування i розвиток підприемств в конкурентному середовищі. Завданнями адаптивного менеджменту $є$ реалізація мети фрункціонування і розвитку підприемства, на основі формування методології, організації процесу адаптивного управління, розробки теоретичних і практичних механізмів реалізації управління у частині стабілізації становища підприемства в конкурентному середовищі, оцінки адаптивності моделі управління тощо.

Адаптивні системи здійснюють свою діяльність на основі наступних принципів [2]:

1. Принцип відповідності керуючої і керованої підсистем, який передбачає, що такі параметри як складність і різноманітність, повинні мати

Генезис сучасних підходів до управління підприемством

Таблиця 1 з позицій адаптації до зовнішнього середовища

\begin{tabular}{|c|c|c|c|}
\hline $\begin{array}{c}\text { Підхід до } \\
\text { управління }\end{array}$ & Представники & Особливості управління & $\begin{array}{c}\text { Способи адаптації до } \\
\text { зовнішнього середовища }\end{array}$ \\
\hline $\begin{array}{l}\text { Процесний (1960 - } \\
\text { по теперішній час) }\end{array}$ & $\begin{array}{l}\text { А. Файоль, } \\
\text { Е. Демінг, } \\
\text { Дж. Джуран } \\
\text { та інші }\end{array}$ & $\begin{array}{l}\text { Управління підприємством } \\
\text { розглядається як процес } \\
\text { послідовного виконання фрункцій } \\
\text { управління }\end{array}$ & $\begin{array}{l}\text { Зовнішне середовище } \\
\text { розглядалось як стабільне, } \\
\text { а відтак способи адаптації } \\
\text { відсутні }\end{array}$ \\
\hline $\begin{array}{l}\text { Системний }(1970- \\
\text { по теперішній час) }\end{array}$ & $\begin{array}{l}\text { П. Друкер, } \\
\text { Ч. Бернард } \\
\text { та інші }\end{array}$ & $\begin{array}{l}\text { Фокусування уваги на цілісності } \\
\text { структури підприемства; орієнтація } \\
\text { на кінцеві показники діяльності } \\
\text { підприемства }\end{array}$ & $\begin{array}{l}\text { Формуються передумови } \\
\text { адаптивного менеджменту, } \\
\text { цільове управління } \\
\text { як спосіб адаптації }\end{array}$ \\
\hline $\begin{array}{c}\text { Ситуаційний } \\
(1980- \\
\text { по теперішній час) }\end{array}$ & $\begin{array}{l}\text { I. Ансофрфр, } \\
\text { Ф. Фідлер } \\
\text { та інші }\end{array}$ & $\begin{array}{l}\text { Орієнтація управління на } \\
\text { сукупність впливів різних факторів, } \\
\text { які класифікують на фактори прямої } \\
\text { і похідної дії }\end{array}$ & $\begin{array}{l}\text { Становлення адаптивного } \\
\text { менеджменту, моніторинг } \\
\text { ракторів зовнішнього } \\
\text { середовища як спосіб адаптаціі }\end{array}$ \\
\hline $\begin{array}{c}\text { Реінжиніринговий } \\
(1990- \\
\text { по теперішній час) }\end{array}$ & $\begin{array}{l}\text { В. Шумахер, } \\
\text { М. Хаммер } \\
\text { та інші }\end{array}$ & $\begin{array}{l}\text { Є продовженням процесного підходу } \\
\text { і дозволяе нівелювати процеси, } \\
\text { не пов'язані з кінцевим результатом }\end{array}$ & $\begin{array}{l}\text { Виокремлення форм адаптації } \\
\text { до зовнішнього середовища - } \\
\text { за рахунок організаційної } \\
\text { структури управління }\end{array}$ \\
\hline $\begin{array}{l}\text { Мережевий (1990 - } \\
\text { по теперішній час) }\end{array}$ & Г. Мінцберг & $\begin{array}{l}\text { Управління підприемством } \\
\text { формується через побудову мереж, } \\
\text { що функціонують на основі } \\
\text { ринкових механізмів }\end{array}$ & $\begin{array}{l}\text { Мережеві структури } \\
\epsilon \text { реакцією на швидко змінне } \\
\text { зовнішне середовище }\end{array}$ \\
\hline $\begin{array}{c}\text { Підхід на основі } \\
\text { управління } \\
\text { знаннями (1990 - } \\
\text { по теперішній час) }\end{array}$ & $\begin{array}{l}\text { Д. Шон, } \\
\text { П. Сенге } \\
\text { та інші }\end{array}$ & $\begin{array}{l}\text { Управління підприемством } \\
\text { здійснюеться на основі } \\
\text { узагальнення, накопичення } \\
\text { та систематизації знань }\end{array}$ & $\begin{array}{l}\text { Самонавчання як один } \\
\text { із способів адаптації }\end{array}$ \\
\hline
\end{tabular}


відповідність між керуючою системою і об'єктом управління. Адаптивні системи не використовують у своїй діяльності певного постійного закону або способу управління.

2. Принцип двоїстого характеру управління. 3 одного боку, керуючий вплив служить безпосередньо для управляють об'єктом, 3 іншого для аналізу його властивостей і закономірностей з метою подальших керуючих більш якісних і ефрективних впливів.

3. Принщип зворотного зв'язку. Зворотній зв'язок служить для вимірювання характеристик керованого об'єкта і згодом фрормулюються і реалізуються реакції, що виражаються в наступних керуючих впливах.

ACM (adaptive case management, dynamic case management, advanced case management, адаптивний кейс-менеджмент, адаптивне ведення справ) - концепція динамічного управління бізнес-процесами підприємства. Вона дає можливість управляти усіма поточними корпоративними проектами і співробітниками, які приймають в них безпосередню участь, повністю контролювати виконання проекту на кожному етапі і формувати бібліотеку «кращих практик» у процесі роботи [5].

На думку деяких експертів, концепція АCM $\epsilon$ альтернативною відносно концепції ВРМ, вирішуючи ті ж завдання ефрективної організації бізнес-процесами, однак іншими інструментами. Існуе також думка, що ACM - це всього лише спрощена версія ВРM, або ж АСM - це доповнення до ВРМ-системи. Заслуговуе на увагу і позиція, згідно з якою, ACM - це «social BPM», в якій наступний крок процесу визначається рішенням людини, що знаходиться в соціальному середовиші [6]. За такого підходу ВРМ і АCM є взаємодоповнюючими, дозволяючи автоматизувати як структуровані, усталені бізнес-процеси підприемства, так і щоденну спільну роботу співробітників.

Пандемія COVID-19 є одним із ключових викликів для бізнесу в сучасних умовах, що охопила усі його аспекти - від галузевих до глобальних ланщюгів постачань. Одночасно 3 коронакризою бізнес переживае "кризу адаптації», навчаючись працювати і отримувати прибуток в нових умовах. Пандемія показала, наскільки обмеженими є ї можливості до швидкого навчання в динамічному світі, коли декілька днів зволікання можуть призвести до чотирикратного зростання кількості інфрікованих і посилення дестабілізаціі бізнесу і суспільства. Оскільки компаніям доведеться адаптуватися до роботи після коронавірусу, вони, перш за все, повинні прискорити темпи своєї цифррової трансформації. Задовго до кризи багато організацій впроваджували програми цифрової трансформації, щоб захистити свої по- зиції від технологій високого порядку конкурентів і скористатися більшою фуункціональністю цифрових бізнес-моделей з їх адаптивністю, продуктивністю і можливістю налаштування під потреби компанії. Нині цифрова трансформація стала першочерговою задачею і для інших підприемств. Спалах COVID-19 прискорила розвиток електронної комерції, а бізнес і споживачі отримали унікальну можливість звикнути здійснювати покупки он-лайн, працювати дистанційно тощо.

За результатами дослідженнями Інституту економічних досліджень та політичних консультацій [7] вітчизняний бізнес можна умовно розподілити на три великі групи. До першої групи відносять підприємства, які припинили свою діяльність через неспроможність працювати в нових умовах, зокрема мікропідприемства, малі і частково середні, пов'язані 3 торгівлею, наданням послуг, пов'язаних з туристичною галуззю тощо. Друга група - це підприемства, які передрорматували свою діяльність у напрямку пропозиції нових товарів і послуг без змін у бізнес-моделі, зокрема торгівля "на виніс", обслуговування в онлайн-режимі і надання послуг, які традиційно були присутні на ринку, однак не настільки популярними. До третьої групи відносять підприемства, які знайшли свою нішу на ринку і розробили нові товари й продукти. Безумовно, в умовах пандемії у сприятливому становищі ті види бізнесу, які змогли перейти на онлайн-роботу.

Висновки і пропозиції. Мінливість середовища господарювання є характерною особливістю розвитку будь-якого підприемства в ринкових умовах. Підприемство фуункціонуе і розвивається в динамічному зовнішньому середовищі, пристосовуючись до його змін. Складність і нестабільність ринкових умов вимагають від підприємства постійного вдосконалення форм і методів господарювання. Для виживання і збереження конкурентоспроможності підприемств в нинішніх умовах потрібні систематичні коригування їх господарської діяльності з урахуванням змін зовнішніх умов. Управління змінами на вітчизняних підприемствах повинно бути орієнтоване переважно не на вирішення існуючих проблем, а на використання наявних можливостей і сильних сторін підприемства. Відтак, для пристосування підприемства до динамічних фракторів зовнішнього середовища підприємству необхідно використовувати одну 3 форм адаптивного управління. Розглядаючи генезис розвитку менеджменту ці форми еволюціонували від найпростіших до більш складних, що базуються на нетривіальних інструментах пристосування.

\section{Список літератури:}

1. Богоявленський О.В., Местоян А.Н. Адаптивне управління підприемством запорука сталого розвитку. Інфраструктура ринку. 2018. Випуск 19. С. 118-121. URL: http://market-infr.od.ua/journals/2018/24_2018_ ukr/23.pdf

2. Стец I.І. Адаптивне управління підприемством. Глобальні та національні проблеми економіки. 2017. Випуск 18. С. 300-305.

3. Тімінський О.Г. Технології адаптивного управління як механізм забезпечення ефективності організаційноуправлінських систем. Управління розвиткол складних систел. 2016. № 27. С. 122-131.

4. Diamanti K., Ioannou L., Baglee D., Pouloudi N. Supportive mechanisms for effective change management. International Journal of Information Systems and Change Management. March 2007, 2(4), $307-333$. DOI: https://doi.org/10.1504/1JISCM.2007.017381 
5. Glonti V., Trynchuk V., Khovrak I., Mokhonko G., Shkrobot M., Manvelidze L. Socialization of Organization Sustainable Development Based on the Principles of Corporate Social Responsibility. Montenegrin Journal of Economics, 2020, 16(1), 169-182. DOI: https://doi.org/10.14254/1800-5845/2020.16-1.11

6. Polinkevych O., Kamiński R. Corporate image in behavioral marketing of business entities. Innovative Marketing. 2018. Volume 14. Issue 1. P. 33-40. DOI: https://doi.org/10.21511/im.14(1).2018.04

7. Бураковський I. Економіка під час ковіду. URL: http://www.ier.com.ua/ua/publications/comments?pid=6551

8. Сіденко В. Глобальні структурні трансформації та тренди економіки України. URL: http://razumkov.org.ua/ uploads/article/EP_18_1_37_uk.pdf

\section{References:}

1. Bohoiavlenskyi O.V., Mestoian A.N. (2018) Adaptyvne upravlinnia pidpryiemstvom - zaporuka staloho rozvytku [Adaptive enterprise management is the key to sustainable development]. Infrastruktura rynku, 19, 118-121. Retrieved from: http://market-infr.od.ua/journals/2018/24_2018_ukr/23.pdf

2. Stets I.I. (2017) Adaptyvne upravlinnia pidpryiemstvom [Ädaptive enterprise management]. Hlobalni ta natsionalni problemy ekonomiky, 18, 300-305.

3. Timinsky A.G. (2016) Tekhnolohii adaptyvnoho upravlinnia yak mekhanizm zabezpechennia efektyvnosti orhanizatsiino-upravlinskykh system [Technologies of adaptive management as a mechanism of support efficiency of organizational management systems]. Upravlinnia rozvytkom skladnykh system, 27, 122-131.

4. Diamanti K., Ioannou L., Baglee D. \& Pouloudi N. (2007) Supportive mechanisms for effective change management. International Journal of Information Systems and Change Management, 2(4), 307-333. DOI: https://doi.org/ 10.1504/1JISCM.2007.017381

5. Glonti V., Trynchuk V., Khovrak I., Mokhonko G., Shkrobot M. \& Manvelidze L. (2020) Socialization of Organization Sustainable Development Based on the Principles of Corporate Social Responsibility. Montenegrin Journal of Economics, 16(1), 169-182. DOI: https://doi.org/10.14254/1800-5845/2020.16-1.11

6. Polinkevych O., Kamiński R. (2018) Corporate image in behavioral marketing of business entities. Innovative Marketing, 14(1), 33-40. DOI: https://doi.org/10.21511/im.14(1).2018.04

7. Burakovskii I. (2021) Ekonomika pid chas kovidu [Economics during the covid]. Retrived from: http://www.ier.com.ua/ $\mathrm{ua} /$ publications/comments?pid=6551

8. Sidenko V. (2018) Hlobalni strukturni transformatsii ta trendy ekonomiky Ukrainy [Global structural transformations and trends of Ukrainian economy]. Retrieved from: http://razumkov.org.ua/uploads/article/ EP_18_1_37_uk.pdf 